Metodički obzori 10, vol. 5(2010)2 Original Research Paper UDK: 343.91-053.5:004

Received: 30. 5. 2010.

\title{
THE ROLE OF PARENTS AND COMPUTER USE OF PUPILS PERPETRATORS OF CRIMINAL ACTS
}

\author{
Mirjana Radetić-Paić, PhD \\ Department of Educational Sciences \\ Juraj Dobrila University of Pula (Croatia) \\ e-mail: mradeticpaic@ hotmail.com \\ Maja Ružić Baf, PhD \\ Department of Educational Sciences \\ Juraj Dobrila University of Pula (Croatia) \\ e-mail: maja@infosit.hr \\ Duška Dragojlović, univ. baccalaurea
}

\begin{abstract}
S u m m ary
When we speak about the potential influence of computer use the most vulnerable segment of the population in particular is that of pupils that go through the process of socialization and who are most susceptible to different influences. The influence of parents on a young person will, in this respect, depend on a serious of characteristics such as the parents' child-rearing practices, their competence to provide timely and adequate intervention, their personality etc. 51

The goals of this work are directed towards detecting the differences for the purpose of which computers are most frequently used and the characteristics of the parents in groups of pupils that perpetrated criminal acts $(\mathrm{N}=100)$ treated by the Centre for social care Pula in the period from 01/04/2004 until 31/3/2007. The purpose of the research is to determine precise indicators for the interpretation of this phenomenon, to provide guidelines for prevention and treatment of pupils that perpetrated various criminal acts and their parents.

The results indicate that the groups of pupils that perpetrated various criminal acts have almost the same characteristics of the parents. There are differences between groups for the purpose of which computers are most frequently used.
\end{abstract}

Keywords: parents, computer use, pupils perpetrators of criminal acts

\section{Introduction}

What are the benefits of the use of the computer for children and which are its negative effects depends on many factors. The effects of the computer can, therefore, be 
both positive and negative and they also depend on the way the computer is used. In both cases these effects are rarely simple and direct, and almost always influenced by many social and other factors (Gunter and McAller, 1997). When talking about the potential effect of the use of computers, the most vulnerable population is pupils. The source of their vulnerability is the fact that they go through the process of socialization and in this age they are mostly subject to various influences in the widest sense, which are relatively difficult to dose and control.

According to the data from the Polyclinic for the Protection of Children in Zagreb, a research carried out in our country showed that the use of computers depended on gender, age, living place, education and parents' employment

(http://poliklinika-djeca.hr/index.php?option=com_content\&task= category\&sectionid $=6 \& \mathrm{id}=27 \&$ Itemid $=52$ ).

Thus, the computer is mostly used by children from big cities and by those whose both parents are employed and have a university degree.

The research by the authors Roberts and partners (1999) dealt with the connection between different demographical and social characteristics and the use of computers by children and the youth. Among other things, the authors expressed the opinion that the media are, in general, a potentially important factor in the socialization of young people, and their effect depends on the choice of the medium, the time of use, the selection of content, the terms of use and different other characteristics such as different groups of children and the youth including those with behavioral disorders.

The way in which children make a difference between the positive and negative characteristics of a computer, between fiction and reality, or choose the right content and grasp the meaning of the presented content depends on many factors, but mostly on parents with whom the young person lives. The parents' influence on a young person will logically, in this sense, be different, and will firstly depend on a group of characteristics such as parents' educational methods, the parents' competence to intervene in time and properly, their personality and many other factors.

Parents have a special place in the process of formation and development of a young person.

The family is the first environment in which a young person lives and in which there are huge possibilities in the process of education. The parents' education depends on many factors. Some can be risky for the manifestation and development of pupils' behavioral disorders, especially when the conditions for the realization of a positive role of the family are not present. It is very common today to talk about the family as an institution in crisis since many changes have occurred and are still occurring. All stated above is upsetting because the pupil needs the support of the family, its strong points, the factors of protection, i.e. all that can help us preventing and fighting the occurrence and development of behavioral disorders.

However, when the use of the computer is in question, regardless of the parents' attitude about that, the pupil will come across computer technology. At the same time, it must not be forgotten that the use of computers has many positive sides like memory development, learning methods, skills of problem solving and the development of 
pupils' ability and self-confidence. Playing computer games can be encouraging for the contact with children of the same age with similar interests. It encourages communication, trains coordination, spacial relations, visualization and other important things. The internet enables a quick accessibility to different information, connection and communication with people, correspondence with children of the same age and from different parts of the world, it teaches young people to solve problems and encourages the development of strategies for the selection of information, exchanging of experiences, thoughts and information with people having similar interests or problems.

On the other hand, the excessive and inadequate use of the computer is often linked to some forms of pupils' behavior (usually violent and aggressive). There is always the unsolved dilemma: does playing violent games and watching violence in general encourage the young viewers to such behavior, and do the existing aggressive characteristics of a young person who watches such contents manifest themselves through a higher tendency toward watching violence.

In the sphere of violent behavior, criminal offences are of different nature and intensity; from insult to murder or from different ways of ill-treatment to felonies connected to terror.

Discussions about criminal violence provoke more anxiety than any other type of criminality, which doesn't surprise since it is a criminal action which takes into account one's personal involvement (Sheley, 1991).

Singer, Kovčo-Vukadin and Cajner-Mraović (2002) point out that in violence and criminality researches a difference was noticed between two types of violence impulsive and instrumental, and that there are three etiological factors of violence in the cultural sense:

- violence as an imitated behavior

- violence as the behavior which determines the value of a group

- violent behavior as the response to "oppressive" society

Violence is usually connected to an expressive aggressiveness of the violent person and their low ability to control aggression. Such a state is usual with young people, which is confirmed by empirical, statistical and clinical facts about the committers of criminal offences with elements of violence (Kovačević, 1979).

The abuse of addictive substances is also an important criminogenous factor which has relatively often been researched in the last time. The abuse of addictive substances by the young is a major problem here (Radetić-Paić, 2004) and in the world, and it became an important source of asocial and antisocial behavior. Although addictive substances have an enormous effect on the young person's health, the abuse of drugs has not only the problem of enjoying, but also its obtaining, production and reselling, which is prone to prosecution in the Republic of Croatia thanks to the positive criminal law. The contemporary psychological and psychiatric knowledge states that the abuse of addictive substances usually exists because of deep personal problems which lead to the sense of tenseness and anxiety, and the reduction of which is obtained in such a way. Boynton (1988) emphasizes that addicts usually have a sense of 
responsibility which is under the average, which consequently leads to unsuccess, and to the sense of lower self-confidence and helplessness. However, the reasons for the tendency of the young to abuse alcohol and drugs can be different; from imitation, fashion, belonging to a group of people of the same age, gaining a more important place in the group or protest against prohibitions.

On the other hand, the huge and branching market of addictive substances is looking for new consumers, and the young with some of the formerly mentioned characteristics which follow the process of growth are a relatively easy target. Although it is usually a question of experimenting with addictive substances, a part of young people does not succeed in keeping control and continues using such substances which leads to addiction and some serious problems which can be hardly solved (Petak, 2005). Among them there are various offences.

Consequently, it is important to point out that in literature (Koller-Trbović, 1995), researches which set the differences between the so-called regular population and the population of small and under age children with behavioral problems are commonly found, while comparisons of small and under age children with behavioral disorders, i.e. committers of criminal offences among themselves are rarely found. The aim of the latter researches would be to produce an accurate diagnosis, find the etiological factors and look for a more effective, differentiated treatment for groups of children and young people with behavioral disorders. Consequently, it can be assumed that the groups of pupils performing various criminal offences will use the computer for different purposes and that the use of computers will affect them in different ways. In this sense, their parents' characteristics play an important role. Since extensive researches for the verification of the aim set do not exist in the accessible literature, we can assume that such researches do exist, and if they really existed, they would offer a better understanding of the phenomenon and determine the preventive and treatment guidelines for pupils who are committers of criminal offences.

\section{Aim, purpose and hypotheses of the research}

This paper is aimed at showing the differences in characteristics of parents and the usual purpose of the use of computers among groups of pupils who are committers of various criminal offences.

The purpose of the research would show a better understanding of the phenomenon and set preventive and treatment guidelines for pupils who are committers of various criminal offences and their parents.

The following hypotheses are tested:

H1: there are statistically important differences in the characteristics of parents of pupils who are committers of various criminal offences with characteristics of violence and committers of criminal offences linked to the abuse of addictive substances.

$\mathrm{H} 2$ : there are statistically important differences in the purpose of the use of computers with pupils who are committers of criminal offences with characteristics of 
violence and committers of criminal offences linked to the abuse of addictive substances.

\section{Methodology}

\section{Sample of examinees}

The research included a sample of 100 pupils who were committers of criminal offences treated by the Centre for Social Care in Pula in the period between 1 April 2004 and 31 March 2007. For the aim of the research the sample was divided into two subsamples formed by pupils:

- committers of criminal offences with elements of violence $(\mathrm{N}=42)$ and

- committers of criminal offences linked to the abuse of addictive substances $(\mathrm{N}=58)$

Chart 1 shows that $86 \%$ of male and $14 \%$ of female pupils took part in the research.

Chart 1 The distribution of examinees according to gender

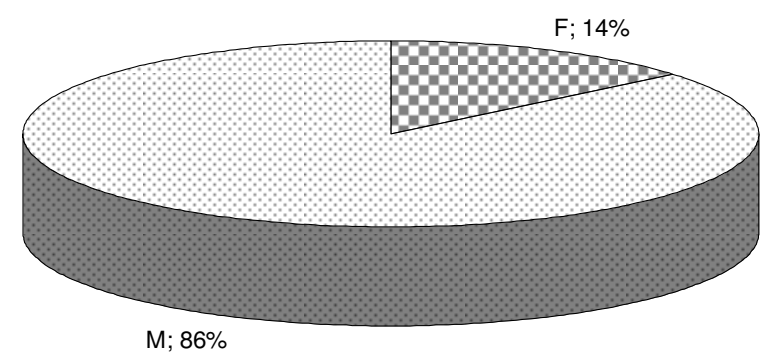

The researched pupils who are committers of criminal offences are mostly 16 to 18 years old (Chart 2$)$.

Generally, $70 \%$ of examinees use the computer daily (Chart 3) which can be considered often (usually for an hour a day). The stated is in line with the quantitative research on the general population $(\mathrm{N}=8534)$ included in the project "Life Quality and the Risk of Social Exclusion in the Republic of Croatia" which considered all the counties (United Nations Development Programme Croatia, 2006), and which led to the conclusion that households owning a personal computer have higher incomes than those not owning it, that rural areas inhabitants own a computer more rarely than those from urban centres, that the part of those using the Internet is often the highest in the City of Zagreb and in the Istria County. When talking about poverty, the project shows that the equivalent income in the Istria County is significantly higher from the average in the 
Republic of Croatia. The use of the Internet is also shown to be more common with men and younger examinees.

Chart 2 The distribution of examinees according to age

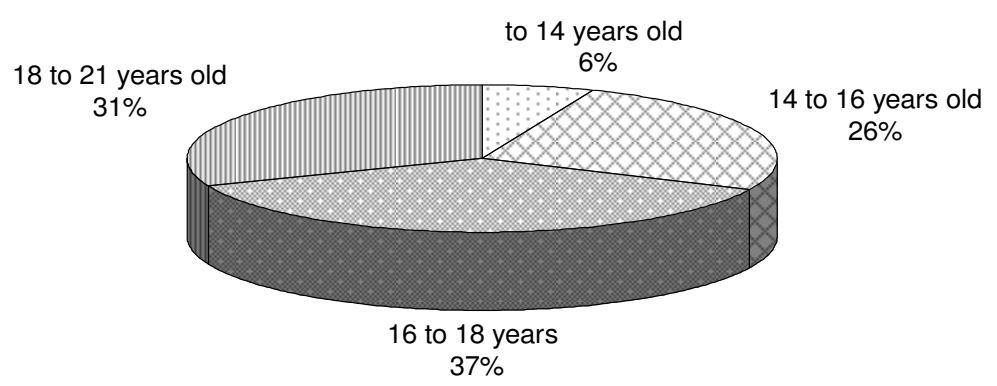

Chart 3 The distribution of examinees according to the time spent using the computer

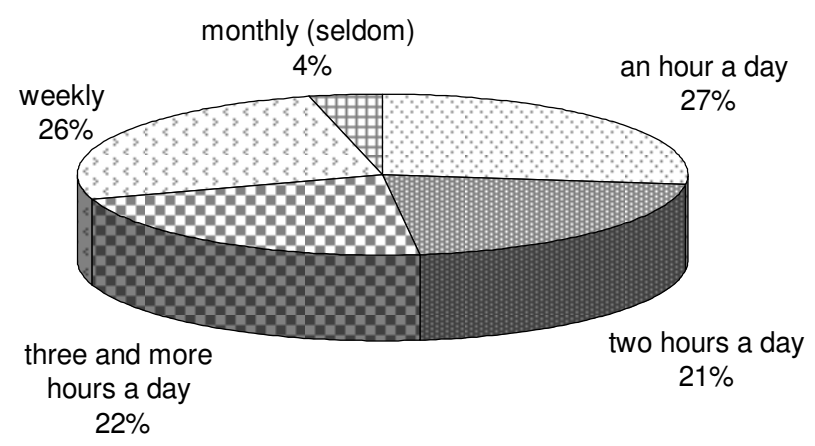

The data from the Centre for Social Care in Pula were used in the research since, on the level of the local community, it has the most complete information about pupils committers of criminal offences, but also about other socio-demographical characteristics relevant to this research.

\section{The sample of variables}

To estimate parents of pupils who are committers of criminal offences in this research, the Form for the Estimation of Risk/Needs of Examinees (originally: The Youth Level of Service/Case Management Inventory) was used. The authors are Hoge, R. D. and Andrews, D. A. (1994; Nikolić, Koller-Trbović and Žižak, 2002) and it referred to the following variables: 
1. the history of the chronic criminal behavior,

2. alcohol - drugs abuse,

3. emotional problems/psychiatric cases,

4. more significant family traumas,

5. uncooperative parents,

6. marriage problems,

7. maltreatment by the father,

8. maltreatment by the mother,

9. financial/housing problems,

10. minority culture/ethnic societies problems.

To define the purposes of using the computer by children and underage committers of criminal offences, a questionnaire was used which was constructed for the needs of this research which consisted of the following six variables:

- $\quad$ writing (Microsoft Word)

- correspondence (e-mail)

- $\quad$ surfing the Internet for school needs

- $\quad$ surfing the Internet independently of school needs

- $\quad$ listening to music - watching movies

- playing games.

\section{Methods of data interpretation}

The $x^{2}$ test along with working out of marginal frequencies was used for the data interpretation.

\section{Ways of data collection}

The research was carried out during 2007 in the Centre for Social Care in Pula, so that the authors of this research, after the interview, filled in the questionnaires mentioned for each of the examinees who entered the sample. It was possible to mark only one most significant characteristic in both questionnaires. The questionnaires were anonymous and used solely for the needs of this research. 


\section{The results of the research and discussion}

The obtained results lead us to the fact that emotional problems/psychiatric cases (Table 1) were the most estimated ones by both examined groups, slightly more by pupil committers of criminal offences with elements of violence. $35 \%$ of pupils committers of criminal offences linked to the abuse of addictive substances marked uncooperative parents while one-fourth of them marked the abuse of drugs or alcohol by their parents. Along with uncooperative parents, the history of chronic criminal behavior and maltreatment by the father was marked relatively high by pupil committers of criminal offences with elements of violence. This can show the existence of violent forms of behavior in those families, i.e. in the transgenerational transfer of such behaviors.

The $x^{2}$ test is 90,322 and it is higher of the marginal value on the ninth level of freedom $(16,919)$ on the level of importance of 0,05 which means that the indicators can be taken as significant, not accidental.

Table 1 Parents' characteristic

\begin{tabular}{|c|c|c|c|c|c|c|c|}
\hline \multirow[b]{2}{*}{ Variable } & & \multicolumn{2}{|c|}{$\begin{array}{l}\text { Pupils committers of } \\
\text { criminal offences with } \\
\text { elements of violence }\end{array}$} & \multicolumn{2}{|c|}{$\begin{array}{l}\text { Pupils committers of } \\
\text { criminal offences } \\
\text { linked to the abuse } \\
\text { of addictive } \\
\text { substances }\end{array}$} \\
\hline & \multicolumn{3}{|c|}{ Chategory } & ap. & $\%$ & ap. & $\%$ \\
\hline Total & & & & 42 & 100 & 58 & 100 \\
\hline \multirow{10}{*}{ 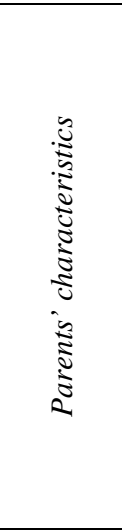 } & \multicolumn{3}{|c|}{$\begin{array}{l}\text { the history of the chronic } \\
\text { criminal behavior }\end{array}$} & 5 & 12 & 1 & 2 \\
\hline & \multicolumn{3}{|c|}{ alcohol - drugs abuse } & 3 & 7 & 15 & 25 \\
\hline & \multicolumn{3}{|c|}{$\begin{array}{l}\text { emotional } \\
\text { problems/psychiatric cases }\end{array}$} & 15 & 36 & 19 & 32 \\
\hline & \multicolumn{3}{|c|}{$\begin{array}{l}\text { more significant family } \\
\text { traumas }\end{array}$} & 3 & 7 & 0 & 0 \\
\hline & \multicolumn{3}{|c|}{ uncooperative parents } & 7 & 15 & 20 & 35 \\
\hline & \multicolumn{3}{|c|}{ marriage problems } & 0 & 0 & 0 & 0 \\
\hline & \multicolumn{3}{|c|}{ maltreatment by the father } & 5 & 12 & 3 & 6 \\
\hline & \multicolumn{3}{|c|}{ maltreatment by the mother } & 2 & 5 & 0 & 0 \\
\hline & \multicolumn{3}{|c|}{ financial/housing problems } & 1 & 3 & 0 & 0 \\
\hline & \multicolumn{3}{|c|}{$\begin{array}{l}\text { minority culture/ethnic } \\
\text { societies problems }\end{array}$} & 1 & 3 & 0 & 0 \\
\hline \multicolumn{8}{|c|}{ Value of Hi-square } \\
\hline & \multicolumn{3}{|c|}{ the significance test } & \multicolumn{4}{|c|}{ symetric measures } \\
\hline & $\begin{array}{c}\text { hi } \\
\text { square }\end{array}$ & df & significance & $\begin{array}{l}\text { contigen. } \\
\text { coeff. }\end{array}$ & $\begin{array}{c}\text { pears-ons } \\
\mathrm{r}\end{array}$ & \multicolumn{2}{|c|}{ spearman correlat. } \\
\hline & 90,322 & 9 & 0,000 & 0,335 & $-0,039$ & \multicolumn{2}{|c|}{$-0,253$} \\
\hline
\end{tabular}

According to the results obtained it can be concluded that certain characteristics of parents are important for the pupils' performing of criminal offences, that they are 
mostly equal for both groups of examinees and that there are not statistically important differences in the parents' characteristics for pupils committers of criminal offences with elements of violence and committers of criminal offences linked to the abuse of addictive substances.

All is confirmed by the indicators which show that parents with emotional problems and those with psychical difficulties are significantly identified as risky factors for the growth and development of the child (Laucht and partners, 1998; Scheithauer and Petermann, 1999). Such parents usually neglect their parental duties, they are inconsistent in their educational methods, and not able to show love and understanding, to communicate properly and control their child, while the whole family is usually characterized by an improper dynamics of relationships, usual conflicts and neglecting, as well as maltreatment of the child.

The author Ajduković (2001) identified maltreatment of the children and the underage as the factor which favors and contributes to the occurrence and development of neurological and intellectual development disorders, school unsuccess and life expectancy, socio-emotional development, social relationships and behavior and mental health on the whole.

In testing the role of the parental educational methods in the development of problematic behavior for children in early adolescence (Raboteg-Šarić and BrajšaŹganec, 2000), a sample of 287 pupils of the $6^{\text {th }}$ and $7^{\text {th }}$ grade coming from average families showed that a weaker parental control and a lower support given to children are connected to all forms of inadequate children behavior, common problematic behavior at school, deviating behavior, smoking and drinking, which is confirmed by the here obtained results.

The research also shows high correlations between criminal behavior of parents and their children behavioral disorders (Towberman, 1992: Papalia and Olds, 1992). These facts must not be simply explained as hereditary characteristics of a person, but as a powerful negative influence of parents and their low capability to socialize their children in a proper way. The authors Rutter and Giller (1983) claim that the characteristic of the criminal behavior of parents is most significantly connected to the occurrence of the same behavior with their children, but they think it is more about a model of antisocial behavior, i.e. their tolerant attitudes toward their unacceptable behavior, than about a direct stimulus to their children for criminal behavior.

Parents usually diminish the threats their children can come across when using the computer, and if the child does not talk about them they tend to think that the children are safe. By avoiding such themes, parents usually protect themselves, not their children. On the other hand, parents are not informed about the threats, and the vast majority of children use the computer in the absence of their parents, surfing without purpose and looking for interesting materials. At the same time, the different, earlier mentioned negative characteristics of parents make the problem of control and purpose of computer use more difficult. The quality of their educational methods, their competence to intervene properly and at the right time, and make their children stronger so that they could recognize the positive and strive against the negative influences of the computer in the widest sense are also questioned. 
Table 2 shows that pupils committers of criminal offences with elements of violence usually use the computer for surfing the internet independently of school $(51 \%)$ and playing games $(18 \%)$. Pupils committers of criminal offences linked to the abuse of addictive substances mostly use the computer to listen to music and watch films (50\%). By working out the $x^{2}$ test the value of 122,826 is gotten. Along with the fifth degree of freedom on the level of significance of 0,05 , the marginal value of the test is 11,070 so these indicators can be taken as significant, not accidental.

Table 2 The purpose of the use of computers

\begin{tabular}{|c|c|c|c|c|c|c|c|}
\hline \multirow[b]{2}{*}{ Variable } & \multirow{2}{*}{\multicolumn{3}{|c|}{ Chategory }} & \multicolumn{2}{|c|}{$\begin{array}{l}\text { Pupils committers of } \\
\text { criminal offences with } \\
\text { elements of violence }\end{array}$} & \multicolumn{2}{|c|}{$\begin{array}{c}\text { Pupils committers of } \\
\text { criminal offences linked to } \\
\text { the abuse of addictive } \\
\text { substances }\end{array}$} \\
\hline & & & & ap. & Variable & Chategory & ap. \\
\hline Total & & & & 42 & Total & & 42 \\
\hline \multirow{6}{*}{ 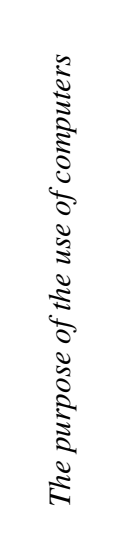 } & \multicolumn{3}{|c|}{$\begin{array}{l}\text { writing (Microsoft } \\
\text { Word) }\end{array}$} & 5 & 12 & 8 & 14 \\
\hline & \multicolumn{3}{|c|}{$\begin{array}{l}\text { correspondence (e- } \\
\text { mail) }\end{array}$} & 4 & 8 & 5 & 8 \\
\hline & \multicolumn{3}{|c|}{$\begin{array}{l}\text { surfing the Internet } \\
\text { for school needs }\end{array}$} & 3 & 6 & 1 & 2 \\
\hline & \multicolumn{3}{|c|}{$\begin{array}{l}\text { surfing the Internet } \\
\text { independently of } \\
\text { school needs }\end{array}$} & 21 & 51 & 8 & 14 \\
\hline & \multicolumn{3}{|c|}{$\begin{array}{l}\text { listening to music - } \\
\text { watching movies }\end{array}$} & 2 & 5 & 29 & 50 \\
\hline & \multicolumn{3}{|c|}{ playing games } & 7 & 18 & 7 & 12 \\
\hline \multicolumn{8}{|c|}{ Value of Hi-square } \\
\hline \multicolumn{5}{|c|}{ the significance test } & \multicolumn{3}{|c|}{ symetric measures } \\
\hline \multicolumn{2}{|c|}{$\begin{array}{l}\text { hi } \\
\text { square }\end{array}$} & $\mathrm{df}$ & $\mathrm{si}$ & nificance & $\begin{array}{l}\text { contigen. } \\
\text { coeff. }\end{array}$ & pears-ons $r$ & $\begin{array}{l}\text { spearman } \\
\text { correlat. }\end{array}$ \\
\hline \multicolumn{2}{|c|}{122,826} & 5 & & 0,000 & 0,485 & $-0,506$ & $-0,509$ \\
\hline
\end{tabular}

The data show that the group of pupils committers of criminal offences with elements of violence usually use the computer to surf the internet independently of school, and it is known that in such a way they can come across inadequate material (the so called cyberbulling), including pornography, materials and pages which enhance hatred, intolerance or discrimination, violent scenes and different misinformation. They can be maltreated or persecuted by people or other children who swear, insult or threaten. There is also the risk of giving personal information when filling in forms or taking part in different online contests. They can also become subject to frauds. Anonymity is made possible by the internet which gives freedom and encourages people to communicate more intimately than they would in personal contacts, and it also gives the possibility of fake acquaintances. 


\section{Conclusion}

On the basis of the obtained indicators the hypothesis by which it is assumed that there are statistically important differences in the characteristics of parents for the two groups of pupils committers of criminal offences (since they have common characteristics) can not be accepted. The hypothesis that there are statistically important differences for the purpose of the use of computers by pupils committers of criminal offences can be accepted. Namely, pupils committers of criminal offences with elements of violence use the computer for surfing the Internet independently from school and for playing games so it can be assumed that such contents had elements of violence and directly or indirectly influenced such children's behavior.

Table 3 Pupils committers of criminal offences with elements of violence: parents' characteristics and the purpose of the use of computers

\begin{tabular}{|l|l|}
\hline \multicolumn{2}{|c|}{ PUPILS - VIOLENCE } \\
\hline \multicolumn{1}{|c|}{ PARENTS: } & \multicolumn{1}{c|}{ PURPOSE OF THE USE OF } \\
COMPUTERS:
\end{tabular}

Table 4 Pupils committers of criminal offences linked to the abuse of addictive substances: parents' characteristics and the purpose of the use of computers

\begin{tabular}{|c|c|}
\hline \multicolumn{2}{|c|}{ PUPILS - ABUSE OF ADDICITIVE SUBSTANCES } \\
\hline \multicolumn{1}{|c|}{ PARENTS: } & PURPOSE OF THE USE OF \\
& COMPUTERS: \\
\hline - emotional problems/psychiatric cases & - listening to music - watching movies \\
$-\quad$ uncooperative parents & \\
- alcohol - drugs abuse & \\
\hline
\end{tabular}

On the basis of the obtained indicators conclusions can be drawn about the connection between parents' characteristics and the purpose of the use of computers for both groups of pupils.

If compared, the obtained indicators can be showed as follows:

The characteristics of parents and pupils committers of criminal offences, when it comes to the use of computers, are important guidelines in planning of adequate prevention and treatment interventions toward parents and pupils under risk or with visible behavioral disorders. Firstly, it is a question of educational, not repressive 
interventions, i.e. interventions which encourage parents' interactions and make the prosocial values in the family stronger (for example, School for Parents or Course for Better Parenthood, or trainings for parents' skills and different supportive programs for more serious problems (Radetić-Paić, 2002)). The education of parents is necessary in the area of risks which children and the youth can come across by using the computer for different purposes as well as for the ways of protection of children while using the Internet. It is necessary to pay attention to other segments and factors of family life and other areas of functioning of a young person which can not be changed by parents' education but which undoubtedly influence the whole family climate and the proper development of a pupil.

\section{Literature}

Ajduković, M. (2001): The Influence of Maltreatment and Neglecting in the Family on the Psychosocial Development of Children. In: The Child and the Society - the Magazine for the Promotion of Children's Rights. Vol. 3. No. 1-2. Pgs. 59-77

Boynton, D.R. (1988): Drug Addiction, Life Style Personality Factors and Psychopathology. Georgia. State University.

Gunter, B. i McAller, J. (1997): Children \& Televison. London and New York.Routledge.

Hoge, R.D. i Andrews, D.A. (1994): The Youth Level of Service/Case Management Inventory: Description and Evaluation. Carleton University. Depatment of Psychology. Ottawa, Ontario K1s 5B6.

Koller-Trbović, N. (1995): Differences in the Self-evaluation of the Self-image by Children with Active and Passive Forms of Behavioral Disorders. Criminology and social interaction. Vol. 3. No. 1. Pgs. 71-76.

Kovačević, V. (1979): Psychological and Social Determinants of Violent Behavior. Defectology 1. Pgs. 45-64.

Laucht, M., Esser, G. i Schmidt, M. H. (1998): Risiko - und Schutzfaktoren der freukindlichen Entwicklung: Empirische Befunde. Zeitschrift fuer Kinder - und Jugendpsychiatrie. 26. 6-20.

Nikolić, B., Koller-Trbović, N., Žižak, A. (2002): Metric Characteristics of the Form for the Evaluation of Risks/Needs (FPRP). Croatian Review for Rehabilitational Researches. Vol. 38. Br. 1. Str.103-119.

Papalia, D.E. i Olds S.W. (1992): Human Development. McGraw-Hill, Inc. New York

Petak, O. (2005): The Role of the Centre for Social Care in the Prevention of Addiction. Collected papers. The conference with international participation "Fight against addiction - fight for a healthy family" Zagreb. Pgs. 205-211.

Polyclinic for the protection of children in the city of Zagreb (http://poliklinikadjeca.hr/index.php?option=com_content\&task=category\&sectionid=6\&id=27\&Itemid=52) 23 March 2009

Raboteg-Šarić, Z., Brajša-Žganec, A. (2000): Parents' Educational Methods and Problematic Children's Behavior in Early Adolescence. Risky and Protection Factors in the Development of Behavioral Disorders of Children and the Youth. Editors Bašić, J. and Janković, J. Commission of the government of the Republic of Croatia for the prevention of behavioral disorders of children and the youth and the protection of children with behavioral disorders. Zagreb. Pgs. 155-170. 
Radetić-Paić, M. (2002): Some Characteristics of Families and Parents as Risky Factors for the Occurrence and Development of Behavioral Disorders with Children and the Youth. Croatian Review For Rehabilitational Researches. 38 (2). Pgs. 133-145.

Radetić-Paić, M. (2004): The Abuse of Addictive Substances and Risky Factors in Families of Children and the Youth with Behavioral Disorders in Pula. Collected papers. The conference with international participation "Fight against addiction-fight for a healthy family" Pula (2004). Pgs. 205210.

Roberts, D.F., Foerh, U.G., Rideont, V.J., Brodie, M.(1999): Kids \& Media. http.//www.kff.org/content/1999/1535/ Middlesex.

Rutter, M. i Giller, H (1983): Juvenile Delinquency. Trends and Perspectives. Penguin Books,

Scheithauer, H. i Petermann, F. (1999): Zur Wirkungsweise von Risiko - und Schutzfaktoren in der Entwicklung von Kindern und Jugendlichen. Kindheit und Entwicklung. 8 (1).3-14.

Sheley, J.G (1991): Criminology. A Contemporary Handbook. Wadsworth Publishing Company.Belmont.California.

Singer, M., Kovčo-Vukadin, I., Cajner-Mraović, I. (2002): Criminology. Globus. Zagreb.

Towberman, D.B. (1992): National Survey of Juvenile Needs Assesment. Crime and Delinquency. Vol. 38. Br.2. Str. 230-238.

United Nations Development Programme Croatia (2006): The quality of life in the Republic of Croatia and the risk for social exclusion. Research project. Target Ltd. For market research. European Foundation for the Improvement of living and Working conditions. Dublin. Ireland.

Metodički obzori 10, vol. 5(2010)2

Izvorni znanstveni rad

UDK: 343.91-053.5:004

Primljeno: 30. 5. 2010.

\section{OBILJEŽJA RODITELJA I UPORABA RAČUNALA UČENIKA POČINITELJA KAZNENIH DJELA}

dr. sc. Mirjana Radetić-Paić, Sveučilište Jurja Dobrile u Puli Odjel za odgojne i obrazovne znanosti e-mail: mradeticpaic@ hotmail.com

dr. sc. Maja Ružić Baf,

Sveučilište Jurja Dobrile u Puli

Odjel za odgojne i obrazovne znanosti e-mail: maja@infosit.hr

Duška Dragojlović, stručna prvostupnica predškolskog odgoja

Sa žetak

Kada govorimo o potencijalnom utjecaju uporabe računala najranjiviji dio populacije su upravno učenici koji prolaze kroz proces socijalizacije i u toj su dobi 
najpodložniji različitim utjecajima. Utjecaji roditelja na mladu osobu će u ovom pogledu ovisiti o nisu obilježja kao što su njihovi odgojni postupci, kompetencije da pravovremeno i odgovarajuće interveniraju, njihova osobnost i sl.

Ciljevi ovog rada usmjereni su ka utvrđivanju razlika u obilježjima roditelja između skupina učenika počinitelja različitih kaznenih djela i u svrsi najčešće njihove uporabe računala $(\mathrm{N}=100)$ koji su bili u tretmanu Centra za socijalu skrb Pula tijekom tri godine. Svrha istraživanja ukazala bi na preciznije tumačenje pojave, određivanje preventivnih i tretmanskih smjernica za učenike počinitelje različitih kaznenih djela i njihove roditelje.

Rezultati pokazuju da promatrane skupine učenika počinitelja različitih kaznenih djela imaju gotovo ista obilježja roditelja, dok se razlikuju u svrsi uporabe računala.

Ključne riječi: obilježja roditelja, korištenje računala, učenici počinitelji kaznenih djela 